\title{
DETERMINANT CAPITAL STRUCTURE OF BANKING COMPANY IN INDONESIA
}

\author{
Elly Astuti ${ }^{1}$ \\ ${ }^{1}$ Accounting Department, Universitas PGRI Madiun \\ ellyastuti@unipma.ac.id
}

\begin{abstract}
This study aims to reveal the factors that affect the capital structure of banking companies in Indonesia. The study of capital structure has been widely documented in Indonesia, but in some previous literature always take out banking companies because of its unique characteristics. Therefore, this research is expected to increase scientific knowledge about the determinant factor of capital structure. The analysis technique used in this research is linear regression with dependent variable: asset turnover, liquidity, collateral, company growth, risk, profitability and company size. The capital structure is proxied by debt to assets ratio with the separation between longterm debt, shortterm debt and total debt. The result of the analysis shows that the determinant factor analyzed can influence the bank capital structure significantly.

Keywords: banking capital structure; longterm debt; short term debt; total debt.

JEL $\quad:$ G32; G21; G30

DOI $: 10.24002 /$ kinerja.v22i1.1236

Received : 27/07/2017 Reviewed : 05/11/2018 Final Version : 03/03/2018
\end{abstract}




\section{INTRODUCTION}

Capital structure is the composition of funding activities of companies derived from internal and external sources. Along with the development of business world, management wants an efficient with optimal capital structure. Optimization of capital structure can be seen from the amount of capital cost incurred by the company. Companies that increase internal funding sources through the issuance of shares will incur a cost in the form of an increase in the amount of dividends paid to shareholders. While the use of external funding sources through the addition of debt, will incur interest costs. For that management should be able to determine which funding decisions will be done.

Modligiani and Miller (1963) unveiled the theory that companies can perform optimal capital structure composition so as to make tax savings and avoid the risk of bankruptcy. Nevertheless the capital structure theory further suggests that the company's funding policy will follow the funding activities hieraki (Donaldson, 1961). Along with the rapidly growing business development, it was found that the company's funding choice policy was also influenced by the company's condition (Ross, 1977). However, when tested further on trade off theory, pecking order theory and free cash flows theory no one can explain the funding behavior of the firm as a whole because each company will consider the costs and benefits in its funding strategy (Myers, 2001).

Based on the theories underlying the composition of the optimal capital structure, various studies related to the growing capital structure. Several previous studies have documented the variables that influence funding decision making with a combination of debt and capital (Chandra, 2014, Facrudin, 2013, Nur and Siahaan, 2016, Sorokina, 2014; Gocmen and Sahin 2014; Chen and Chen, 2011). Basically the determinants of the capital structure of some of these studies include profitability, collateral owned by the company, company growth, business risk and liquidity position. However, in some previous studies, the focus of the discussion was more emphasis on nonfinancial companies. Therefore, in this research will be focused on banking companies as one of the financial sub-sector which has different characteristics with previous research.

The unique characteristics of banks are; tax benefits on a larger banking company than a non-financial company, lower bankruptcy costs, agency issues will be greater in companies with higher debt levels, information asymmetry is more important for banks to raise capital costs (Gropp and Heider, 2009). In addition, in conducting its operational activities, banking companies are heavily influenced by some very strict regulations, such as regulations from OJK, PAPI, PSAK and some other rules issued by Bank Indonesia, so it is possible that the regulation will also have a different effect on financing options by a banking company.

Banking companies have the main operational activities of collecting funds from the community and channeling them back to business owners. The operational activities, enabling the company to optimize the funding sources of short-term and long-term debt sourced from customer deposits. The banking company will describe different phenomena in its funding decision strategy. The difference of this study with previous research is the industry segment under study 
and testing the capital structure that is more focused on short-term debt and longterm debt.

Based on some previous research, the factors used in testing the capital structure are asset turnover, corporate liquidity, collateral, corporate growth, risk, profitability and firm size. Asset turnover is a measurement normally used to determine the efficiency level of the company's allocation of wealth. The small amount of asset turnover, shows the company is more efficient in managing its wealth so it can finance its operational activities from internal sources of retained earnings. The greater the asset turnover value indicates that the company's management is less able to improve the company's wealth so that additional operational funding is required from external activities. Based on these assumptions, asset turnover has a positive effect on the company's capital structure.

Liquidity is the company's ability to meet its short-term obligations. The higher liquidity ratio indicates better corporate financial performance, so it may not require funding from external parties. Based on these assumptions, the company's liquidity is expected to negatively affect the company's capital structure.

When a company wants to expand its business through external funding primarily from debt, the creditor will require collateral. The greater the level of guarantee owned by the company, the greater the trust of creditors to provide loans, so in this study it is suspected the magnitude of corporate guarantee is positively related to the company's capital structure.

Companies that are experiencing rapid growth will require substantial funding for its expansion activities. Internal funding sources are considered inadequate. For this reason, the fast-growing companies are looking for external sources of funding, thus the company's growth is expected to have a positive effect on the company's capital structure.

Risks can be seen from the fluctuations in profits earned by the company. The higher level of profit fluctuations obtained by the company indicates the greater risk contained in the company. Increasing corporate risk makes the cost of capital higher. In addition, an increased risk will reduce the confidence of external parties to invest in shares or provide loan debt. Based on these assumptions, the company's risk will negatively affect the capital structure.

Profitability is the company's ability to generate profits. The higher profitability of the company, the greater retained earnings that can be accumulated to fund the next operational activities. The adequacy of internal funds makes the company does not require additional funding from external parties either from the issuance of bonds, bank loans or the issuance of new shares. Based on these assumptions, profitability will have a negative effect on the company's capital structure.

Greater operational management of the company will be better, transparent and professional, so the risk of bankruptcy from large companies will be smaller. Based on this assumption, large companies will be easier to obtain external funding, so the size of the company is expected to have a positive effect on the company's capital structure. 


\section{RESEARCH METHODS}

\subsection{Population and Sample}

The population in this study is all banking companies listed on the Stock Exchange in 2014-2016. The number of companies registered in 2016 is 43 companies. The sampling technique used purposive sampling with some predetermined criteria. The final sample size is 21 companies for 3 years so that the number of observation is 63 companies.

Table 1. Number of Research Sample

\begin{tabular}{clc}
\hline No & \multicolumn{1}{c}{ Criteria } & Total \\
\hline 1 & Companies are listed on the IDX in the banking sector & 43 \\
2 & The company moved sector / delisting during observation & $(8)$ \\
3 & The period of the company's financial statements is not as of December 31 & $(0)$ \\
4 & Companies that use foreign currency denominations & $(0)$ \\
5 & he Company suffered losses during observation & $(9)$ \\
6 & The company experienced negative growth & $(2)$ \\
7 & Outlier & $(3)$ \\
\hline & Number of Samples & $\mathbf{2 1}$ \\
\hline & Total observation 24 x 3 & $\mathbf{6 3}$ \\
\hline
\end{tabular}

\subsection{Data collection technique}

This study uses secondary data types obtained from the web BEI (idx.co.id). All dependent and independent variable data is obtained from the company's financial statements 2014-2016.

\subsection{Variables and Definitions of Operational Variables}

\subsubsection{Dependent Variables}

Dependent variable in this research is capital structure. Capital structure is the proportion of debt used to finance operational activities. Capital structure is calculated by comparing the amount of debt with total assets owned by the company, or can be formulated as follows:

$$
\text { Capital Structure }=\frac{\text { Total Debt }}{\text { TotalAssets }}
$$

\subsubsection{Independent Variables} Asset Turn Over

Asset turnover reflects the level of efficient use of corporate wealth to carry out operational activities. Asset turnover is calculated by comparing total sales with total assets, or can be formulated as follows:

$$
\text { Assets Turn Over }=\frac{\text { Total Sales }}{\text { TotalAssets }}
$$

Regarding the sample in this study is a banking company, sales are meant in the formula is the amount of interest income. 


\section{Liquidity}

The liquidity position illustrates the company's ability to meet its short-term liabilities. The calculation of liquidity position is done by comparing the total current assets with current liabilities, or can be formulated as follows:

\section{Collateral}

$$
\text { Liquidity }=\frac{\text { Current Assets }}{\text { Current Liabilities }}
$$

Collateral illustrates the amount of company assets that can be guaranteed to obtain external financing especially from debt. To calculate the size of a company's collateral can be done by comparing the total current assets owned by the company (cash, bank, securities, securities, derivatives and other financial assets) plus fixed assets compared to total assets, or can be formulated as follows:

$$
\begin{aligned}
& \text { Collateral } \\
& =\frac{\text { Cash }+ \text { Bank }+ \text { Securities }+ \text { Derivative Financial Assets }+ \text { FixedAssets }}{\text { TotalAssets }}
\end{aligned}
$$

\section{Company Growth}

The growth of the company reflects the company's opportunity to further develop in the future. The growth of this company can be seen from the percentage change of assets owned by the company from year to year, or can be formulated as follows:

$$
\text { Company growth }=\frac{\text { total assets this year }- \text { total assets last year }}{\text { total assets last year }} \times 100 \%
$$

Risk

Each company has its own inherent risk. Companies at risk can be seen from the fluctuations in profits obtained. The higher the profit fluctuations the company gains, indicating the greater the risk it faces in the future. To calculate the risk the company can use the following formula:

$$
\text { Risk }=\text { StandardDeviation of EBIT }
$$

Profitability

Profitability is the company's ability to generate profits in the future. This studi use $\mathrm{ROA}$ and ROE to calculate profitability of the company. The formula for calculating $\mathrm{ROA}$ and ROE is as follows:

$$
\text { ROA }=\frac{\text { net income }}{\text { totalassets }} R O E=\frac{\text { net income }}{\text { equity }}
$$

Size

The size of the firm affects the level of public confidence in the company primarily in obtaining external sources of financing using debt. The size of this company is calculated by using the total natural log of assets owned by the company. 


\section{DATA ANALYSIS TECHNIQUE}

Data analysis technique used in this research is linear regression, with equation as follows:

$$
\begin{gathered}
\text { DAR }_{i t}=\propto+ \\
+\beta_{1} \text { ATO }_{i t}+\beta_{2} \text { Liquidity }_{i t}+\beta_{3} \text { Collateral }_{i t}+\beta_{4} \text { Growth }_{i t}+\beta_{5} \text { Risk }_{i t} \\
+\beta_{6} \text { ROA }_{i t}+\beta_{6} \text { ROE }_{i t}+\beta_{6} \text { Size }_{i t}
\end{gathered}
$$

Keterangan:

DAR

: Comparison of debt with assets owned by the company. In this research, DAR variable will be examined with some effect if DAR only uses short term debt, DAR only uses long-term debt, and DAR uses total debt.

ATO : Asset Turnover is the ratio between total sales and total assets.

Liquidity : Comparison of current liabilities with current assets.

Collateral : The amount of collateral owned by the company to obtain funding.

Risk : The inherent risk of the company is based on pre-tax profit fluctuations.

ROA : Comparison of the company's net income with assets.

ROE : Comparison of the company's net income with equity.

Size : Logaritma natural of total assets.

\section{ANALYSIS AND DISCUSSION}

Table 2 shows the results of the regression by measuring the level of debt using short-term debt, long-term debt and total debt. It is used to distinguish the impact of several economic factors on short-term and long-term funding options.

Asset turnover (ATO) is used to measure the efficiency of corporate asset utilization. ATO has a negative effect on capital structure with short-term debt ratio. ATO is a comparison between the company's main revenue compared to total assets owned. The main income of the banking company is obtained from the difference between the interest income on the loan and the interest charged to the savings and deposits of customers, as well as the cost of service administration. ATO with the capital structure of short-term debt ratio is negatively related because the higher income earned by the company indicates the difference between interest income on loan and the greater deposit interest of the customer and the administrative cost of the service charged to the bigger customer. The low interest rates on deposits and deposits are certainly less attractive to customers.

While the capital structure with long-term ratio shows a positive relationship. This indicates that external funding sources are needed to lend to customers. This is due to a less balanced comparison between the amount of funds collected from the community and the amount of funds disbursed through loans. Therefore, to meet the amount of loans required by the community, banks seek an alternative to long-term debt financing. External parties, evaluating bank performance based on the amount of funds absorbed by the community, the higher the absorption of 
funds, is predicted to be able to increase the bank's income from the loan interest. This is certainly more attractive to long term creditors.

Table 2. Regression Analysis Results

\begin{tabular}{|c|c|c|c|c|c|c|}
\hline \multirow[t]{2}{*}{ Variabel } & \multicolumn{2}{|c|}{$\begin{array}{c}\text { DAR } \\
\text { (Short Term Debt) }\end{array}$} & \multicolumn{2}{|c|}{$\begin{array}{c}\text { DAR } \\
\text { (Long Term Debt) }\end{array}$} & \multicolumn{2}{|c|}{$\begin{array}{c}\text { DAR } \\
\text { (Total Debt) }\end{array}$} \\
\hline & $\beta$ coef. & Sig. & $\beta$ coef. & Sig. & ßcoef. & Sig. \\
\hline Constant & 1,446 &, 000 &,- 533 &, 000 & ,912 &, 000 \\
\hline ATO &,- 442 &, 021 & ,482 & ,001 & 040 & ,723 \\
\hline Liquidity &,- 068 & ,000 & ,000 & ,886 &,- 068 &, 000 \\
\hline Collateral &,- 005 & ,807 &,- 035 &, 040 &,- 040 & ,004 \\
\hline Growth &,- 001 & ,001 &, 000 &, 166 &, 000 &, 000 \\
\hline Risk & $4,474 \mathrm{E}-15$ & 081 & $-5,636 \mathrm{E}-16$ & .767 & $3,913 \mathrm{E}-15$ & .014 \\
\hline ROA & $-9,460$ &, 000 &, 473 &, 534 & $-8,986$ &, 000 \\
\hline ROE & 1,379 & ,000 &,- 254 & ,054 & 1,124 & ,000 \\
\hline Size &,- 037 & ,000 & ,040 & ,000 & 0,004 & ,499 \\
\hline $\begin{array}{l}\text { Value of } \mathbf{R}^{2} \\
\text { Adjusted } \mathbf{R}^{2}\end{array}$ & \multicolumn{2}{|c|}{$\begin{array}{l}936 \\
926\end{array}$} & \multicolumn{2}{|c|}{,554 } & \multicolumn{2}{|c|}{,973 } \\
\hline Value of $F$ & \multicolumn{2}{|c|}{$\begin{array}{l}, 926 \\
98.288\end{array}$} & \multicolumn{2}{|c|}{$\begin{array}{l}\text {,488 } \\
8.393\end{array}$} & \multicolumn{2}{|c|}{$\begin{array}{c}, 969 \\
247,275\end{array}$} \\
\hline
\end{tabular}

The liquidity of banking companies has a significant negative effect on the capital structure with the ratio of short-term debt and total debt. These results are in accordance with Cekrezi (2013a), Hossain and Ali (2012), Hadi (2014), Enakirerhi and Chijuka (2016). The company's liquidity reflects the company's ability to meet its short-term liabilities. The higher corporate liquidity indicates that the company's internal funding position is so strong that it does not require external funding sources. Therefore, liquidity has a negative effect on the company's capital structure. These results are consistent with the research of Cekrezi (2013a) and Hosain and Ali (2012). It also supports pecking order theory which states that companies will prioritize the use of internal funding sources, then just consider external sources.

Liquidity has no effect on capital structure with long-term ratio. Viewed from the short-term side, according to the analysis above the high level of liquidity indicates that the good corporate performance so that no need to seek external sources of funds. However, high liquidity indicates that there is a large amount of money in the company and is not well utilized. Therefore, high liquidity also creates a high interest rate sacrifice from the company, so that the prospective creditor is less interested to provide long-term loans to companies with high liquidity.

Collateral reflects the amount of collateral held by the company required when the company seeks external sources of funds. The higher the company's collateral will be, the easier it will be for companies to get funding from external sources. But in this study collateral does not affect the short-term capital structure. This is due to the short-term debt of the banking company is the funds collected from customers. When customers save or make deposits, customers tend to consider more interest rates offered bank, liquidity and health of the bank concerned. Thus the collateral does not affect the capital structure with the ratio of short-term debt. 
While in capital structure with long-term ratio and total debt, collateral has negative effect. The results are in accordance with Sayeed (2011) but not in accordance with the initial hypothesis which assumes that higher collateral leads to higher capital structure obtained from external parties. The higher the amount of collateral owned by the company, that's the amount of assets that can be optimized for the operational activities of the company and lead the company for creating profit from its operational activities. The availability of high corporate retained earnings leads to good stability, so no additional funding from external parties is required. This is in accordance with pecking order theory.

The risk positively affects the capital structure with the ratio of total debt, at the $5 \%$ and $10 \%$ significance levels in the capital structure to the short-term debt ratio, but does not affect the capital structure with the long-term debt ratio. This result is in accordance with Cekrezi (2013b). In its operational activities, bank risk becomes the main concern of the customers because of several cases of banking performance for decades which are very detrimental to customers and destabilize the national economy. Nevertheless, this study can not prove that risk affects the capital structure with long debt ratio. This is likely due to the very short observation range 2014-2016, so that the impact of profit fluctuations as a proxy of risk has little effect on long-term debt of banking companies.

Profitability proxied by ROA and ROE affects the banking capital structure in the opposite direction. ROA has a negative effect on the capital structure with the ratio of short-term debt and total debt. These results are in accordance with research by Cekrezi (2013b), Hossain and Ali (2012), Enakirerhi and Chijuka (2016). Nevertheless the results of this study, ROA does not affect the capital structure with long-term debt ratio. While ROE gives positive influence to capital structure with long-term debt ratio, but give negative effect to capital structure with ratio of short-term debt and total debt.

The size of the firm negatively affects the capital structure with the ratio of short-term debt. This happens because the larger the size of banking companies, stricter in applying the rules of credit. In addition, interest rates offered to customers who deposit funds in the form of savings or deposits have been relatively stable following market interest. These conditions make the customer less interested. The emergence of new banks that offer product innovation and higher interest rate also makes the customer divert funds deposits.

However, the view does not apply to long-term lender creditors. The result of regression analysis shows that firm size has a positive effect on capital structure with long-term debt ratio. This result is in accordance with the preposition trade off theory and Cekrezi (2013a), Enakirerhi and Chijuka (2016), Sayeed (2011). The larger the size of the company, the higher the creditor's confidence to lend as it takes into account the ability of the company to repay its loan in accordance with the agreed agreement.

\section{CONCLUSIONS AND RECOMMENDATIONS}

The purpose of this study is to reveal the factors that affect the capital structure in banking companies in Indonesia. This study analyzes the capital 
structure by separating the analysis using long-term debt, short-term debt and total debt. The analysis results show the influence of each factor with different ratios produce different impact. Overall, this study supports pecking order theory which states that companies will have a tendency to use internal funding sources to meet their operational needs. In some circumstances, this study also supports trade off theory, where large companies will benefit from taxes by using external funding sources. The unique characteristic that distinguishes banking companies from other companies primarily in the capital structure is that the banking company will prioritize the source of short-term debt financing obtained from the funds collected from the customer.

Limitations in this study are very short research periods so as not being able to capture macroeconomic symptoms such as inflation rate, crisis conditions and other conditions that may affect alternative selection of bank financing sources. In the next research is expected to add variable tax management, intellectual capital investment primarily for human capital development, and earnings management that may influence the decision of the funding structure of the company. In future studies are also expected to test the prepositions of the overall capital structure theory which includes pecking order theory, trade off theory and incorporating free cash flows assumption.

\section{REFERENCES}

Cekrezi, A. 2013. Impact of Firm Level Factors on Capital Structure Decision: An Empirical Study of Albanian Firms. European Journal of Sustainable Development. 2(4), pp.135-148.

Cekrezi, A. 2013. Anayzing the Impact of Firm's Specific Factors and Macroeconomic Factors on Capital Structure: A Case of Small Non-Listed Firms in Albania. Research Journall of Finance and Accounting. 4(8), pp.9096.

Chandra, T. 2014. Faktor-Faktor yang Memengaruhi Struktur Modal Pada Perusahaan Properti dan Real Estate di Indonesia. Ekuitas: Jurnal Ekonomi dan Keuangan. 18(4), pp.507-523.

Chang, C. 1999. Determnants of Capital Structure and Management Compensation: The Partial Square Approach. ProQuest Dissertations and Theses.

Chen, S.Y dan Chen L.J. 2011. Capital Structure Determinants: An Empirical Study in Taiwan. African Journal of Business Management 5(27), pp.10974-10983.

Donaldson G. 1961. Corporate debt capacity: A study of corporate debt policy and the determination of corporate debt capacity. Boston, division of Research, Harvard Graduate School Of Business Administration 
Enakirerhi, L.I, dan Chijuka, M.I. 2016. The Determinants of Capital Structure of FTSE 100 Firms in the UK: A Fixed Effect Panel Data Approach. Research Journal of Finance and Accounting. 7(13), pp.59-73

Fachrudin, K.A. 2013. Determinan Preferensi Struktur Modal Usaha Mikro dan Kecil. Ekuitas: Jurnal Ekonomi dan Keuangan. 17(3), pp.318-336.

Gocmen, T dan Sahin, O. 2014. The Determinants of Bank Capital Structure and the Global Fiancial Crisis: The Case of Turkey. Journal of Applied Finance \& Banking. 4(5), pp.55-67.

Gropp, R. dan Heider, F. 2009. Determinants of Bank Capital Structure. European Central Bank Working Paper Series 1096, pp.1-50.

Hadi, A.H. 2014. Determinants of Capital Structure: A Comparative Study in Malaysia and Indonesia. Universitas Utara Malaysia (UUM) Repocitory.

Hossain, F., dan A. Ali. 2012. Impact of Firm Specific Factors on Capital Structure Decision: An Empirical Study of Bangladeshi Companies. International Journal of Business Research and Management (IJBRM). 3(4), pp163-182.

Li Yao. 2014. The Determinants of Capital Structure of Real Estate Companies: Evidence from China. Universitas Utara Malaysia (UUM) Repocitory.

Modigliani dan Miller. 1963. Corporate Income Taxes on the Cost of Capital: A Correction. American Economic Review. 53(3), pp.433-443

Myers, S.C. 2001. Capital Structure. The Journal of Economic Perspectives. 15 (2), pp.81-102.

Nur, T dan Siahaan, S.P. 2016. Determinan Struktur Modal dan Nilai Perusahaan. ESENSI. 19(3), pp.1-18.

Ross, S.A. 1977. The Determinant of Financial Structure: The Incentive Signalling Approach. The Bell Journal of Economics. 8 (1), pp.23-40

Sayeed, M.A. 2011. The Determinants of Capital Structure for Selected Bangladeshi Listed Companies. International Review of Business Research Papers 7(2), pp.21-36.

Sorokina, N.Y. 2014. Bank Capital and Theory of Capital Structure. ProQuest LLC 